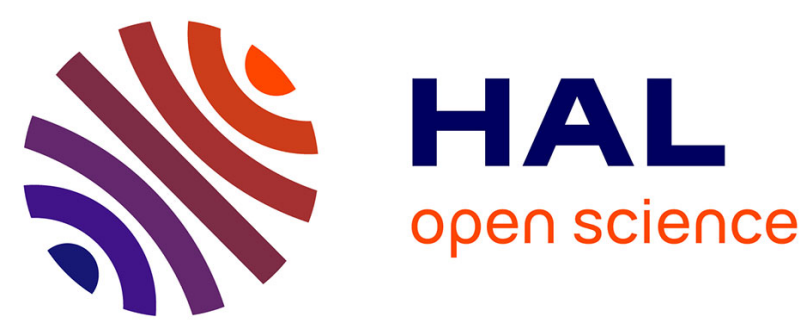

\title{
WNT4 is Expressed in Human Fetal and Adult Ovaries, and Its Signaling Contributes to Ovarian Cell Survival
}

Minna Jääskeläinen, Renata Prunskaite-Hyyryläinen, Florence Naillat, Helka

Parviainen, Mikko Anttonen, Markku Heikinheimo, Annikki Liakka, Roxana

Ola, Seppo Vainio, Tommi E. Vaskivuo, et al.

\section{To cite this version:}

Minna Jääskeläinen, Renata Prunskaite-Hyyryläinen, Florence Naillat, Helka Parviainen, Mikko Anttonen, et al.. WNT4 is Expressed in Human Fetal and Adult Ovaries, and Its Signaling Contributes to Ovarian Cell Survival. Molecular and Cellular Endocrinology, 2010, 317 (1-2), pp.106. 10.1016/j.mce.2009.11.013 . hal-00559593

\section{HAL Id: hal-00559593 https://hal.science/hal-00559593}

Submitted on 26 Jan 2011

HAL is a multi-disciplinary open access archive for the deposit and dissemination of scientific research documents, whether they are published or not. The documents may come from teaching and research institutions in France or abroad, or from public or private research centers.
L'archive ouverte pluridisciplinaire HAL, est destinée au dépôt et à la diffusion de documents scientifiques de niveau recherche, publiés ou non, émanant des établissements d'enseignement et de recherche français ou étrangers, des laboratoires publics ou privés. 


\section{Accepted Manuscript}

Title: WNT4 is Expressed in Human Fetal and Adult Ovaries, and Its Signaling Contributes to Ovarian Cell Survival

Authors: Minna Jääskeläinen, Renata Prunskaite-Hyyryläinen, Florence Naillat, Helka Parviainen, Mikko Anttonen, Markku Heikinheimo, Annikki Liakka, Roxana Ola, Seppo Vainio,

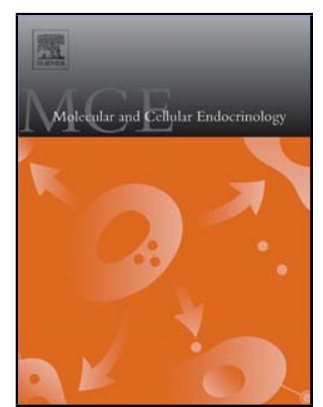

Tommi E. Vaskivuo, Juha S. Tapanainen

PII:

S0303-7207(09)00578-4

DOI: doi:10.1016/j.mce.2009.11.013

Reference: MCE 7377

To appear in: $\quad$ Molecular and Cellular Endocrinology

Received date: $\quad$ 1-9-2009

Revised date: 20-10-2009

Accepted date: 13-11-2009

Please cite this article as: Jääskeläinen, M., Prunskaite-Hyyryläinen, R., Naillat, F., Parviainen, H., Anttonen, M., Heikinheimo, M., Liakka, A., Ola, R., Vainio, S., Vaskivuo, T.E., Tapanainen, J.S., WNT4 is Expressed in Human Fetal and Adult Ovaries, and Its Signaling Contributes to Ovarian Cell Survival, Molecular and Cellular Endocrinology (2008), doi:10.1016/j.mce.2009.11.013

This is a PDF file of an unedited manuscript that has been accepted for publication. As a service to our customers we are providing this early version of the manuscript. The manuscript will undergo copyediting, typesetting, and review of the resulting proof before it is published in its final form. Please note that during the production process errors may be discovered which could affect the content, and all legal disclaimers that apply to the journal pertain. 
WNT4 is Expressed in Human Fetal and Adult Ovaries, and Its Signaling Contributes to Ovarian Cell Survival

Minna Jääskeläinen ${ }^{\mathrm{a}, \mathrm{b}}$, Renata Prunskaite-Hyyryläinen ${ }^{\mathrm{c}, \mathrm{d}}$, Florence Naillat ${ }^{\mathrm{c}, \mathrm{d}}$, Helka

Parviainen $^{\text {f,g,h }}$, Mikko Anttonen ${ }^{\text {g,h }}$, Markku Heikinheimo ${ }^{\mathrm{f}, \mathrm{j}}$, Annikki Liakka ${ }^{\mathrm{e}}$, Roxana Ola ${ }^{\mathrm{i}}$, Seppo Vainio $^{\mathrm{c}, \mathrm{d}}$, Tommi E. Vaskivuo ${ }^{\mathrm{b}}$, Juha S. Tapanainen, ${ }^{\mathrm{a}, \mathrm{b}, *}$

${ }^{a}$ Department of Obstetrics and Gynecology, Oulu University Hospital, Finland;

${ }^{\mathrm{b}}$ Clinical Research Center, Oulu University Hospital, Finland

'Oulu Center of Cell-Matrix Research, Biocenter Oulu, Laboratory of Developmental Biology, ${ }^{\mathrm{d}}$ Institute of Biomedicine, Department of Medical Biochemistry and Molecular Biology and

e Department of Pathology, University of Oulu, Finland;

fChildren's Hospital, University of Helsinki, Finland;

'Program for Women's Health, University of Helsinki, Finland;

${ }^{\mathrm{h}}$ Department of Obstetrics and Gynecology, University of Helsinki, Finland;

${ }^{\mathrm{i}}$ Biochemistry and Developmental Biology Group Institute of Biomedicine, University of Helsinki, Finland;

jDepartment of Pediatrics, University of Washington, St. Louis, USA

Department of Obstetrics and Gynecology, P.O. Box 5000, 90014, University of Oulu, Finland Tel: +358-8-3153172 Fax: +358-8-3154310, juha.tapanainen@oulu.fi 
Keywords: WNT4, apoptosis, oocyte, granulosa cell, (human ovary)

\begin{abstract}
:
WNT4 plays an important role in female sexual development and ovarian function. WNT4deficiency leads disturbed development of the internal genitalia in mouse and human, and to a dramatic reduction of mouse oocytes. However, the expression and role of WNT4 in human ovaries is yet unknown. The expression of WNT4 mRNA and protein was studied in human adult and fetal ovaries (gestational ages 12-41 weeks), and the role of Wnt4 in oocyte apoptosis was investigated in Wnt4-deficient mice. WNT4 mRNA and protein were present in human ovaries throughout fetal development and in different follicular stages in adult ovaries. Compared with wild-type mice, Wnt4-deficient mice had a markedly enhanced rate of oocyte apoptosis, with the highest values at gestational ages of 14.5 and 16.5 days post-coitum. The current results support a view that WNT4 may have a role in oocyte selection and follicle formation and maturation in human ovaries.
\end{abstract}




\section{Introduction:}

The locally acting excreted glycoprotein WNT4 is a member of the WNT (wingless-type MMTV integration site family) family of extracellular ligands (Cadigan, Nusse 1997, Vainio et al. 1999). The action of the WNT4 ligand is transmitted through receptors located on the cellular membrane, most importantly those of the Frizzled family (Cadigan, Liu 2006). This canonical $W n t$ signaling pathway eventually leads to nuclear accumulation of $\beta$-catenin and transcriptional regulation of target genes (Cadigan, Liu 2006). Wnt genes have been highly conserved throughout evolution and Wnt signaling has been observed to play a role in a wide variety of physiological and pathological events from embryogenesis to the onset and development of cancer.

Wnt4 has an important role in female sexual differentiation (Vainio et al. 1999, Jeays-Ward et al. 2003, Kim et al. 2006, Ottolenghi et al. 2007). It is downregulated in male gonads after the initiation of testicular development (11.5 days post-coitum [dpc]) while it is persistent in the developing ovary (Vainio et al. 1999). Mice with homozygous mutation in the Wnt4 gene have severely disturbed development of the internal genitalia and ovaries. Wnt4-deficient ovaries are masculinized, with a round and non-encapsulated form and they develop in close association with a fat body structure. Female mutant mice lack Müllerian ducts and have male-type Wolffian ducts instead (Vainio et al. 1999). In addition to their masculinized appearance, mutant ovaries express many Leydig and Sertoli cell markers and secrete testosterone and Müllerian-inhibiting substance (MIS) (Heikkila et al. 2001, Heikkila et al. 2005).

WNT4 plays an important role also in human sex determination. Female patients with loss-of-function mutation in the WNT4 gene have developmental abnormalities mimicking the phenotype observed in Wnt4 mutant mice. They are partially masculinized, with clinical features of primary amenorrhea, androgen excess, regressed Müllerian duct derivatives and anomalous location of the ovaries (BiasonLauber et al. 2004, Biason-Lauber et al. 2007).

By the time of birth, the number of oocytes in Wnt 4 mutant mouse ovaries is abnormally low (Vainio et al. 1999). Wnt4 has not been shown to affect the number of primordial germ cells in the undifferentiated gonad, but it is thought to act as an oocyte survival factor during female embryogenesis (Vainio et al. 1999, Heikkila et al. 2001). The massive germ cell loss in Wnt4-deficient mice occurs most rapidly at $16.5 \mathrm{dpc}$, when more than $90 \%$ of the oocytes are being depleted (Yao et al. 2004). At this time, apoptotic oocytes can be detected in the central region of both wild-type and mutant ovaries, but in contrast to the normal ovary, rapid apoptosis takes place in the ovarian cortices of Wnt4-deficient mice (Yao et al. 2004).

During normal ovarian development, Bcl-2 family genes are central in the regulation of oocyte apoptosis. The family contains several anti- and pro-apoptotic factors which have been shown to be important in the regulation of apoptosis in mouse ovaries. Oocytes of $B c l X_{L^{-}}$deficient mice undergo massive apoptosis (Rucker et al. 2000), while knockout of pro-apoptotic Bax results in a decreased rate of oocyte apoptosis (Perez et al. 1999, Alton, Taketo 2007). In addition to the Bcl-2 family, numerous other factors are associated with the regulation of ovarian apoptosis. For instance, TRAIL, a tumor necrosis factor-related apoptosis-inducing ligand, has been shown to participate in the regulation of apoptosis in mammalian ovaries (Inoue et al. 2003, Jaaskelainen et al. 2009). Moreover, several transcriptional factors such as GATA-4 and its co-factor FOG-2 participate in the regulation of oocyte survival in mice and men (Heikinheimo et al. 1997, Vaskivuo et al. 2001, Anttonen et al. 2003).

In the present work the expression of WNT4 mRNA and protein was studied for the first time during human fetal development and human adult follicular maturation. In addition, apoptosis and the expression of key apoptosis-regulating factors in Wnt4-deficient and in wild-type mouse ovaries were analyzed in detail to evaluate the contribution of Wnt4 signaling to survival of the maturing oocytes. 


\section{Materials and methods:}

\section{Human ovarian tissue samples}

Fetal ovarian tissue samples were obtained from 7 fetuses (aged 12-23 wk) after spontaneous or therapeutic abortion and from 9 fetuses (aged 22-41 wk) after intrauterine death followed by spontaneous or induced delivery or cesarean section. In addition, ovaries from 6 neonates (gestational age 23, 26, 27, 31,35 and 38 weeks) who died because of perinatal asphyxia or infection within 30 min-3 days after birth were studied. The obduction data of all female fetuses during the years 2000-2007 at Oulu University Hospital were examined and on the basis of the information all samples with chromosomal abnormalities, significant anomalies or autolysis were excluded. Thereafter, a pediatric pathologist analyzed the morphology of the remaining samples, and samples with signs of autolysis in HE-staining were further excluded. Three fetuses included in the study were diagnosed as having chorioamnionitis. However, their ovaries were morphologically intact and did not have any signs of infection. All fetuses and neonates had normal karyotypes. Adult ovarian tissues were obtained from 19 premenopausal patients aged 22-49 years undergoing ovariectomy because of endometriosis. In addition, human adrenal gland and testis were used as control tissues. All samples were fixed in $4 \%$ buffered formaldehyde for 24 hours and embedded in paraffin. Histological sections $(4 \mu \mathrm{m})$ were cut and processed for immunohistochemistry and in situ hybridization. The study was approved by the Ethics Committees of Oulu University Hospital and the University of Oulu. A permit to study human autopsy tissues and resection material was obtained from the Finnish National Authority for Medicolegal Affairs.

\section{Generation of Wnt4 mutant mice:}

Wnt4 +/- mice in SV129 background were crossed to obtain -/- embryos and the genotypes were analyzed as described earlier (Heikkila et al. 2005, Stark et al. 1994). Female wild-type and Wnt4-deficient mouse embryos aged 12.5, 14.5 and $16.5 \mathrm{dpc}$ and newborn animals were studied.

\section{Immunohistochemistry:}

Immunohistochemistry for WNT4 was performed on human ovarian paraffin-embedded tissues. Paraffin sections were first incubated at $37^{\circ} \mathrm{C}$ for $30 \mathrm{~min}$ and then at $60^{\circ} \mathrm{C}$ for $30 \mathrm{~min}$. Deparaffinization was carried out in xylene and the tissues were hydrated gradually through a series of graded alcohols. Pretreatment in Tris- $\mathrm{HCl}$ in a microwave oven $(700 \mathrm{~W}$ for $2 \mathrm{~min}$ and $300 \mathrm{~W}$ for $15 \mathrm{~min}$ ) was performed. Tissues were then cooled at RT for $20 \mathrm{~min}$. Endogenous peroxidase activity was blocked with 3\% hydrogen peroxide in methanol. The sections were then washed in $\mathrm{dH}_{2} \mathrm{O}$ and PBS. Diluted normal serum provided with the immunostaining kit (Vectastain Elite ABC Kit, Vector laboratories, Burlingame, CA) was used to block nonspecific binding sites. Primary antibody against WNT4 protein (Santa Cruz Biotechnology, Inc., Santa Cruz, CA; cat. no. sc-5214) at a concentration of 1:50 in background-reducing antibody diluent (Dako, Glostrup, Denmark) was added to the samples and they were incubated under plastic cover slips in a humidified chamber overnight at $+4{ }^{\circ} \mathrm{C}$. A commercially available avidin-biotin immunoperoxidase system was used to visualize bound antibodies (Vectastain Elite ABC Kit, Vector laboratories, Burlingame, CA).

Immunohistochemistry involving mouse ovarian tissues was performed following a standard protocol. Primary antibodies against Bcl- $\mathrm{X}_{\mathrm{L}}(1: 800)$, Bok (1:100), TRAIL (1:50), GATA-4 (1:200) and FOG-2 (1:200) (Santa Cruz Biotechnology, Inc., Santa Cruz, CA, USA; cat. nos. sc-7122, sc-11424, sc-6079, sc1237 and sc-10755, respectively) and aromatase (1:500) (Acris Antibodies, Hiddenhausen, Germany, cat. no. BP278), diluted in PBS, were used. A commercially available avidin-biotin immunoperoxidase system was used to visualize bound antibodies (Vectastain Elite ABC Kit, Vector laboratories, Burlingame, CA). 
In situ hybridization

Probes for WNT4 in situ hybridization were prepared from a commercially available WNT4 cDNA clone in pBluescriptR vector (Image clone 30330746, Genbank accession no BC057781, MCR geneservice, Cambridge, UK).

Human tissue sections were hybridized with single-stranded antisense and sense RNA probes of human WNT4. The plasmid containing WNT4 cDNA was linearized with EcoRI for the antisense and BamHI for the sense RNA probes. The RNA probes were labeled with digoxigenin-UTP by in vitro transcription with T3/T7 polymerase using a DIG RNA Labeling Kit (Roche Diagnostics GmbH, Mannheim, Germany). $200 \mathrm{ng}$ of the probe was used in the hybridization, and the sense probe was used as a negative control. In situ hybridization was carried out with Ventana Discovery automatic staining instrument using commercial buffers (Roche Diagnostics GmbH, Mannheim, Germany). The DIG labelled probe was detected with monoclonal biotinylated anti-digoxigenin antibody (Jackson ImmunoResearch Laboratories Inc., PA) used at 1:2000 dilution and with the BlueMap kit (Roche Diagnostics GmbH, Mannheim, Germany).

In situ DNA 3' end-labeling:

Apoptosis was studied by using an Apoptag ${ }^{\circledR}$ Peroxidase In Situ Apoptosis Detection Kit (Millipore, Billerica, MA) as previously described (Vaskivuo et al. 2001). The instructions of the manufacturer were followed. Briefly, paraffin-embedded tissues were deparaffinized in xylene and rehydrated through a series of graded alcohols. The tissues were pretreated in proteinase $\mathrm{K}(4 \mathrm{mg} / \mathrm{ml})$ and $3 \%$ hydrogen peroxide before applying the enzyme deoxynucleotidyl transferase (TdT) to the samples. Incubation took place under plastic cover slips in a humidified chamber at $37^{\circ} \mathrm{C}$ for one hour. Bound enzyme was visualized with anti-digoxigenin antibody and diaminobenzidine tetrahydrochloride $(15 \mu \mathrm{l} / \mathrm{ml})(\mathrm{DAB}$, DakoCytomation Ltd., Ely, UK). The samples were counterstained with hematoxylin.

\section{Sample analysis:}

Immunohistochemical and in situ hybridization stainings were analyzed by two independent observers.

For analysis of apoptosis the ovarian samples from Wnt4-deficient and wild-type animals were photographed using Qimaging MicroPublisher 5.0 RTV and Qcapture-Pro software. The size of each tissue section was then measured (ImageJ program) and apoptotic cells were counted and the results adjusted to section size. The data was analysed by using SPSS 15.0 software (SPSS, Chicago, IL, USA). The data is presented as arithmetic mean plus SD. Student's $t$ test were used for analyses of signicance and a value of $p<0.05$ was considered significant. 


\section{Results}

\section{WNT4 mRNA and protein are expressed in human fetal ovaries}

The in situ hybridization analyses showed strong expression of WNT4 mRNA in human ovaries at all fetal ages studied. Both granulosa cells and oocytes expressed WNT4 mRNA (Fig. 1 a). Similarly, immunostaining of WNT4 protein was detected in human ovaries throughout fetal development (Fig. 2A a-h). During early ovarian development (12-18 weeks), moderate WNT4 protein expression was mainly localized to pregranulosa and granulosa cells and only weak protein expression could be detected in oocytes, recognized by their round appearance and large amount of cytoplasm (Fig. 2A, a and b). As follicle formation proceeded, staining intensity tended to increase, but more samples would be needed to confirm this observation (Fig 2A c-f). During the latter half of fetal development strong WNT4 mRNA and protein expression was observed mainly in oocytes, but granulosa cells in primordial and primary follicles were also moderately stained (Figs. 1 a; 2A, e-h).

\section{WNT4 $m R N A$ and protein are present during follicular maturation in human adult ovaries}

WNT4 mRNA was expressed in granulosa cells and oocytes of primordial/primary and secondary follicles (Fig. $1 \mathrm{c}$ ) and in granulosa and theca cells of the antral follicles (Fig. 1 e). Immunohistochemical staining of WNT4 protein was observed at all stages of follicular maturation. In small primordial/primary follicles the oocytes were strongly positive for WNT4 (Fig. 2B, a). Greater magnification showed that granulosa cells in these follicles were also positively stained (Fig. 2B, c). Interestingly, in antral follicles, moderate WNT4 staining was detected in theca cells while granulosa cells were stained weakly (Fig. 2B, e). In all samples staining was located mainly in the cytoplasm.

Human adrenal gland and testis were used as control tissues in immunohistochemistry and in situ hybridizations. Adrenal gland showed strong WNT4 mRNA and protein expression (Fig. $1 \mathrm{~g}$; $2 \mathrm{~B}, \mathrm{~g}$ and h). Only weak expression was observed in human adult testis, mainly localized to Leydig cells (Fig. 1 i; 2B, i and j). Similar Wnt4 expression pattern has been previously detected in marsupial adult testis (Yu et al. 2006).

\section{Increased oocyte apoptosis in Wnt4-deficient mice}

Apoptosis was detected in the ovaries of fetal and newborn wild-type and mutant mice (Fig. 3, A-H). Most of the apoptotic cells presented typical morphological features of germ cells including large size and round cytoplasm. In both genotypes the apoptosis rate increased after mid-pregnancy, reaching a maximum at $16.5 \mathrm{dpc}$ (Fig. 3, E and F) and then declining towards birth. When comparing the numbers of apoptotic cells in Wnt4 mutant and wild-type mice, a significantly higher number of apoptotic cells was observed in Wnt4-deficient ovaries at $14.5 \mathrm{dpc}$ (Fig. 3, C and D) and the difference was most pronounced at $16.5 \mathrm{dpc}$ (Fig. 3, E and F). In the ovaries of newborn mice the rate of apoptosis was similar in Wnt4 wild-type and mutant mice (Fig. 3, G and H).

\section{Apoptosis regulating factors in Wnt4-deficient mouse ovaries}

Immunohistochemical staining of Bcl- $\mathrm{X}_{\mathrm{L}}$, Bok, TRAIL, GATA-4, FOG-2 and aromatase showed that these proteins were similarly expressed in the ovaries of mutant and wild-type mice during fetal development (Fig 4). Expression of the pro-apoptotic Bcl-2 family member Bok was restricted mainly to oocytes (Fig 4, e and f). In both genotypes Bok was observed in the oocytes of the medullar and cortex regions of the ovary. The cytokine-like apoptosis-inducing ligand TRAIL (Fig 4, a and b), the antiapoptotic mitochondrial membrane protein Bcl- $\mathrm{X}_{\mathrm{L}}$ (Fig 4, c and d) and aromatase (Fig 4, k and l) were expressed in oocytes and somatic cells in both Wnt4-deficient and wild-type ovaries throughout fetal development. GATA-4 (Fig 4, $g$ and $\mathrm{h}$ ) and its cofactor FOG-2 (Fig 4, i and j) were expressed mainly in pregranulosa and granulosa cells of mutant and wild-type ovaries. 


\section{Discussion:}

In the present study we demonstrate the expression of WNT4 mRNA and protein in human ovaries during fetal development and fertile life. These results support the role of WNT4 in human ovarian development and its importance in normal ovarian function (Biason-Lauber et al. 2004, Biason-Lauber et al. 2007). The expression of WNT4 protein in human fetal ovaries was high during mid-pregnancy, when new follicles are also rapidly being formed. This implies that WNT4 may have a substantial role in regulation of the follicle formation in human ovaries, as also demonstrated in Wnt4-deficient animals, which lack proper follicle structures (Vainio et al. 1999). Moreover, WNT4 mRNA and protein were present in ovaries later during fetal life and in adult ovaries, supporting a view that WNT4 may also have a role in follicular development and maturation in human ovaries (Philibert et al. 2008).

Wnt4 mRNA has previously been shown to be expressed in rodent ovaries during fetal development (Vainio et al. 1999, Barrionuevo et al. 2006) and its expression increases in young females after the primordial follicles are formed (Hsieh et al. 2002). In human ovaries a somewhat similar tendency was observed. WNT4 was detected throughout the fetal development and the strongest expression of WNT4 took place after follicular formation when oocyte apoptosis starts to decrease (Vaskivuo et al. 2001). The observed WNT4 expression pattern in human ovaries and the markedly increased apoptosis rate in Wnt4deficient mouse ovaries suggest that WNT4 may be an important factor in the selection of human follicles that either survive or become deleted from the ovary.

In adult human ovaries $W N T 4$ mRNA and protein were expressed in the small primary and growing secondary follicles. Antral follicles expressed WNT4 variably and in addition to granulosa cells the theca cells surrounding the follicles were also positive. This suggests that WNT4 may be involved in the regulation of all cell compartments. Similarly to our finding in human ovaries, Wnt4 mRNA is expressed in small growing follicles and in preovulatory and ovulatory follicles in mouse ovaries (Hsieh et al. 2002).

In adult and fetal human ovaries WNT4 mRNA and protein were detected both in the granulosa cells and in the oocytes. There has not been general agreement on the cellular localization of WNT4 in the ovary. The results of previous studies on mice suggest that Wnt4 is expressed in granulosa cells rather than germ cells (Vainio et al. 1999, Yu et al. 2006). On the other hand, Wnt4 mRNA has been detected in oocytes in postnatal chick ovaries (Oreal et al. 2002). Although oocytes are known to show nonspecific immunostaining, the present results raise the possibility that WNT4 expression also takes place in human germ cells. However, comparison of results from mice and humans might also point towards species-specific differences in the expression pattern of Wnt4.

The expression of apoptosis-regulating factors was studied in the ovaries of Wnt4-deficient and wild-type mice by immunohistochemistry. Several analyses were performed with primary antibodies against TRAIL, Bok, Bcl-X $\mathrm{X}_{\mathrm{L}}$, GATA-4, FOG-2 and aromatase. No significant differences were observed in the expression patterns of these proteins between Wnt4-deficient and wild-type animals. Thus our results suggest that increased apoptosis in the absence of Wnt 4 action is not directly caused by a significant change in the expression levels of the factors known to regulate apoptosis in ovaries and other organs. Further studies are, however, needed to comprehend fully the mechanisms of WNT4 in regulating apoptosis in ovaries.

To conclude, WNT4 mRNA and protein are present in human fetal and adult ovaries and ovarian apoptosis is significantly enhanced in Wnt4 mutant mice when compared with wild-type animals. The results support a view that $W N T 4$ may have a role of in the regulation of oocyte survival, follicle formation and follicle maturation in human ovaries. More robust studies on the molecular mechanisms are needed to understand the protective role of WNT4 in oocyte demise. 


\section{Acknowledgements:}

Special thanks go to Petri Itäranta and Kirsi Sainio for help with the in situ hybridization analyses. We thank Dr. Riitta Herva for collecting fetal tissues and Johanna Arola for providing human adrenal gland tissue. We also thank Nick Bolton for revising the language.

Grants: The project was supported by grants from the Academy of Finland (M.H., S.V., T.E.V., J.S.T.), the Sigrid Jusélius Foundation (M.H., S.V., J.S.T.), Oulu University Hospital (J.S.T.) and The Europian Union (S.V., LSHG-CT-2004-005085). 


\section{References}

Alton M., Taketo T., 2007. Switch from BAX-dependent to BAX-independent germ cell loss during the development of fetal mouse ovaries. J.Cell.Sci. 120, 417-424.

Anttonen M., Ketola I., Parviainen H., Pusa A.K., Heikinheimo M., 2003. FOG-2 and GATA-4 Are coexpressed in the mouse ovary and can modulate mullerian-inhibiting substance expression.

Biol.Reprod. 68, 1333-1340.

Barrionuevo F., Bagheri-Fam S., Klattig J., Kist R., Taketo M.M., Englert C., Scherer G., 2006. Homozygous inactivation of Sox9 causes complete XY sex reversal in mice. Biol.Reprod. 74, 195-201.

Biason-Lauber A., De Filippo G., Konrad D., Scarano G., Nazzaro A., Schoenle E.J., 2007. WNT4 deficiency--a clinical phenotype distinct from the classic Mayer-Rokitansky-Kuster-Hauser syndrome: a case report. Hum.Reprod. 22, 224-229.

Biason-Lauber A., Konrad D., Navratil F., Schoenle E.J., 2004. A WNT4 mutation associated with Mullerian-duct regression and virilization in a 46,XX woman. N.Engl.J.Med. 351, 792-798.

Cadigan K.M., Liu Y.I., 2006. Wnt signaling: complexity at the surface. J.Cell.Sci. 119, 395-402.

Cadigan K.M., Nusse R., 1997. Wnt signaling: a common theme in animal development. Genes Dev. 11, 3286-3305.

Heikinheimo M., Ermolaeva M., Bielinska M., Rahman N.A., Narita N., Huhtaniemi I.T., Tapanainen J.S., Wilson D.B., 1997. Expression and hormonal regulation of transcription factors GATA-4 and GATA-6 in the mouse ovary. Endocrinology 138, 3505-3514.

Heikkila M., Peltoketo H., Vainio S., 2001. Wnts and the female reproductive system. J.Exp.Zool. 290, 616-623.

Heikkila M., Prunskaite R., Naillat F., Itaranta P., Vuoristo J., Leppaluoto J., Peltoketo H., Vainio S., 2005. The partial female to male sex reversal in Wnt-4-deficient females involves induced expression of testosterone biosynthetic genes and testosterone production, and depends on androgen action. Endocrinology 146, 4016-4023.

Hsieh M., Johnson M.A., Greenberg N.M., Richards J.S., 2002. Regulated expression of Wnts and Frizzleds at specific stages of follicular development in the rodent ovary. Endocrinology 143, 898-908.

Inoue N., Manabe N., Matsui T., Maeda A., Nakagawa S., Wada S., Miyamoto H., 2003. Roles of tumor necrosis factor-related apoptosis-inducing ligand signaling pathway in granulosa cell apoptosis during atresia in pig ovaries. J.Reprod.Dev. 49, 313-321.

Jaaskelainen M., Kyronlahti A., Anttonen M., Nishi Y., Yanase T., Secchiero P., Zauli G., Tapanainen J.S., Heikinheimo M., Vaskivuo T.E., 2009. TRAIL pathway components and their putative role in granulosa cell apoptosis in the human ovary. Differentiation 77, 369-376.

Jeays-Ward K., Hoyle C., Brennan J, Dandonneau M., Alldus G., Capel B. \& Swain A., 2003. Endothelial and steroidogenic cell migration are regulated by WNT4 in the developing mammalian gonad. Development 130, 3663-3670. 
Kim Y., Kobayashi A., Sekido R., DiNapoli L., Brennan J., Chaboissier M.C., Poulat F., Behringer R.R., Lovell-Badge R. \& Capel B., 2006. Fgf9 and Wnt4 act as antagonistic signals to regulate mammalian sex determination. PLoS Biol. 4, e187.

Oreal E., Mazaud S., Picard J.Y., Magre S., Carre-Eusebe D., 2002. Different patterns of anti-Mullerian hormone expression, as related to DMRT1, SF-1, WT1, GATA-4, Wnt-4, and Lhx9 expression, in the chick differentiating gonads. Dev.Dyn. 225, 221-232.

Ottolenghi C., Pelosi E., Tran J., Colombino M., Douglass E., Nedorezov T., Cao A., Forabosco A., Schlessinger D., 2007. Loss of Wnt4 and Foxl2 leads to female-to-male sex reversal extending to germ cells. Hum Mol Genet. 16, 2795-804.

Perez G.I., Robles R., Knudson C.M., Flaws J.A., Korsmeyer S.J., Tilly J.L., 1999. Prolongation of ovarian lifespan into advanced chronological age by Bax-deficiency. Nat.Genet. 21, 200-203.

Philibert P., Biason-Lauber A., Rouzier R., Pienkowski C., Paris F., Konrad D., Schoenle E., Sultan C., 2008. Identification and functional analysis of a new WNT4 gene mutation among 28 adolescent girls with primary amenorrhea and mullerian duct abnormalities: a French collaborative study.

J.Clin.Endocrinol.Metab. 93, 895-900.

Rucker E.B.3rd, Dierisseau P., Wagner K.U., Garrett L., Wynshaw-Boris A., Flaws J.A., Hennighausen L., 2000. Bcl-x and Bax regulate mouse primordial germ cell survival and apoptosis during embryogenesis. Mol.Endocrinol. 14, 1038-1052.

Stark K., Vainio S., Vassileva G., McMahon A.P., 1994. Epithelial transformation of metanephric mesenchyme in the developing kidney regulated by Wnt-4. Nature 372, 679-683.

Vainio S., Heikkila M., Kispert A., Chin N., McMahon A.P., 1999. Female development in mammals is regulated by Wnt-4 signalling. Nature 397, 405-409.

Vaskivuo T.E., Anttonen M., Herva R., Billig H., Dorland M., te Velde E.R., Stenback F., Heikinheimo M., Tapanainen J.S., 2001. Survival of human ovarian follicles from fetal to adult life: apoptosis, apoptosis-related proteins, and transcription factor GATA-4. J.Clin.Endocrinol.Metab. 86, 3421-3429.

Yao H.H., Matzuk M.M., Jorgez C.J., Menke D.B., Page D.C., Swain A., Capel B., 2004. Follistatin operates downstream of Wnt4 in mammalian ovary organogenesis. Dev.Dyn. 230, 210-215.

Yu H., Pask A.J., Shaw G., Renfree M.B., 2006. Differential expression of WNT4 in testicular and ovarian development in a marsupial. BMC Dev.Biol. 6, 44. 


\section{Figure Legends}

Figure 1. WNT4 mRNA expression in human fetal and adult ovaries. WNT4 mRNA expression was observed in all of the fetal ovaries studied (a). Sense control (b).

In adult human ovaries WNT4 mRNA was expressed in oocytes and granulosa cells of primordial/primary follicles (c). In growing antral follicles strong WNT4 labeling was detected in granulosa and theca cells (e). Sense controls (d and f).

Human adrenal gland tissue was used as positive control and showed strong WNT4 expression (g). Weak WNT4 mRNA expression could also be detected in Leydig cells of adult human testes (i). Sense controls (h and j).

Blue color indicates mRNA expression. ${ }^{*}=$ Oocyte, arrows indicate granulosa cells. Scale bar $100 \mu \mathrm{m}$. 

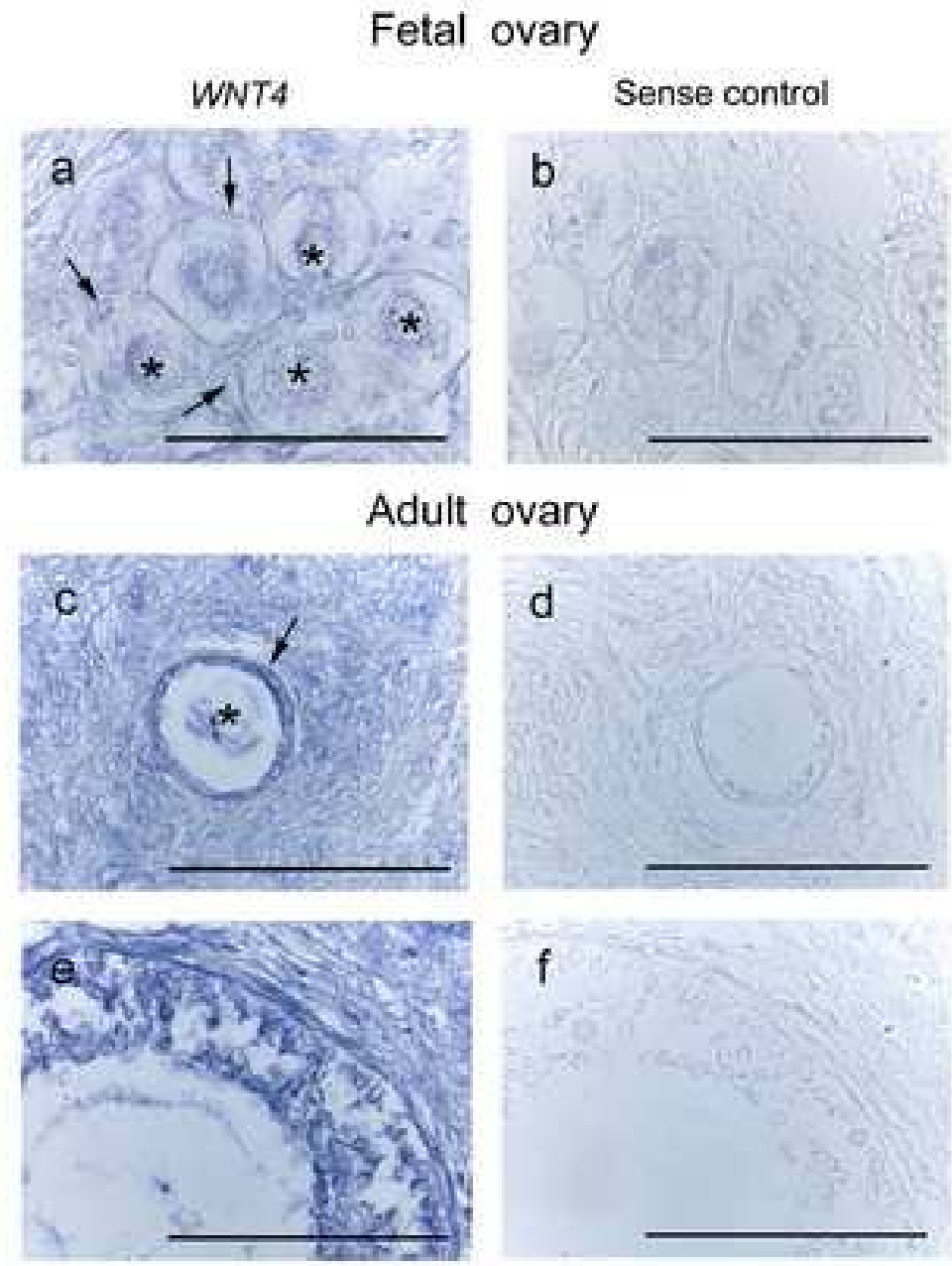

Adrenal gland

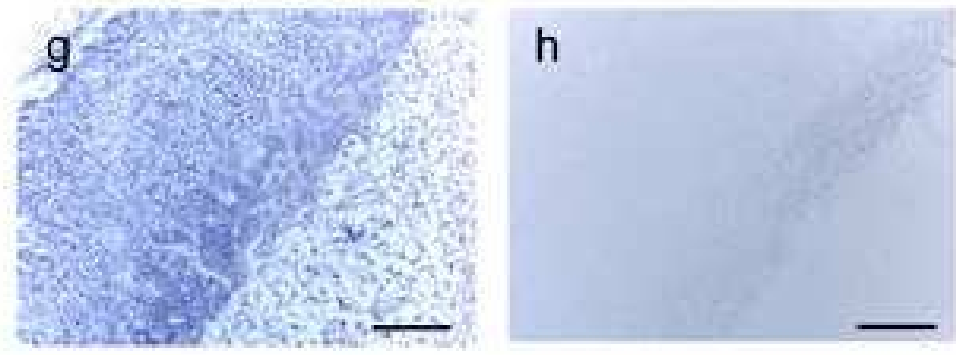

Testis

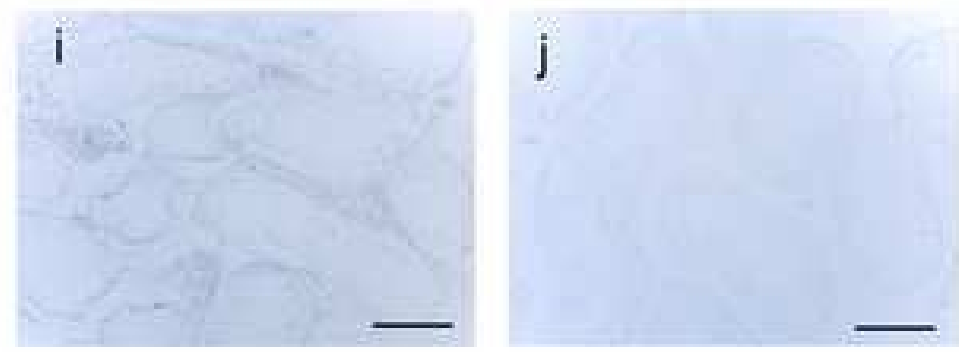


Figure 2. WNT4 protein expression in human fetal (A) and adult (B) ovaries. WNT4 protein was detected in human ovaries at all fetal ages studied. During early development, staining was mainly present in granulosa cells, while the oocytes (with round shape and a large cytoplasm) showed weak expression (A: $a$ and $b$ ). From fetal age 19 weeks onwards, staining intensity in oocytes tended to increase (A: $\mathrm{c}$ and $\mathrm{d}$ ). After midgestation strong/moderate WNT4 protein expression was detected in most of the follicle-encapsulated oocytes, and granulosa cells were also moderately stained (A; e-h). Negative control using PBS instead of primary antibody (A: $i$ and $j)$.

Staining of WNT4 was intense in primary and secondary follicles of adult human ovaries and was detected mainly in oocytes, but also granulosa cells were moderately stained (B: a and c). In antral follicles granulosa cells were weakly stained and moderate staining was observed in theca cells (B: e). Negative control using PBS instead of primary antibody (B: $b, d$ and $f$ ).

Human adrenal gland (B: $g$ and $h$ ) and testis (B: $i$ and j) were used as control tissues. Strong staining was detected in adrenals while in human testis tubular cells showed only negligible and Leydig cells moderate staining.

Brown color indicates protein expression. $*=$ Oocyte, arrows indicate granulosa cells. Scale bar $100 \mu \mathrm{m}$. 
A

Fetal ovary
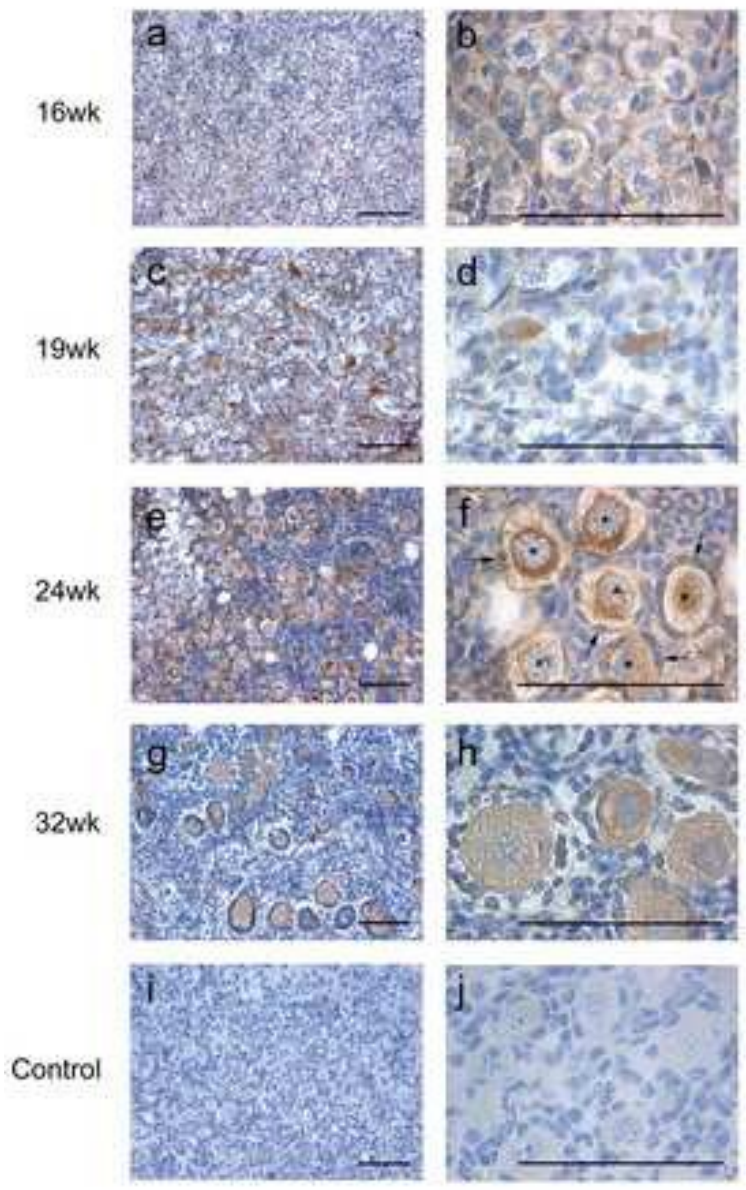

B

Adult ovary
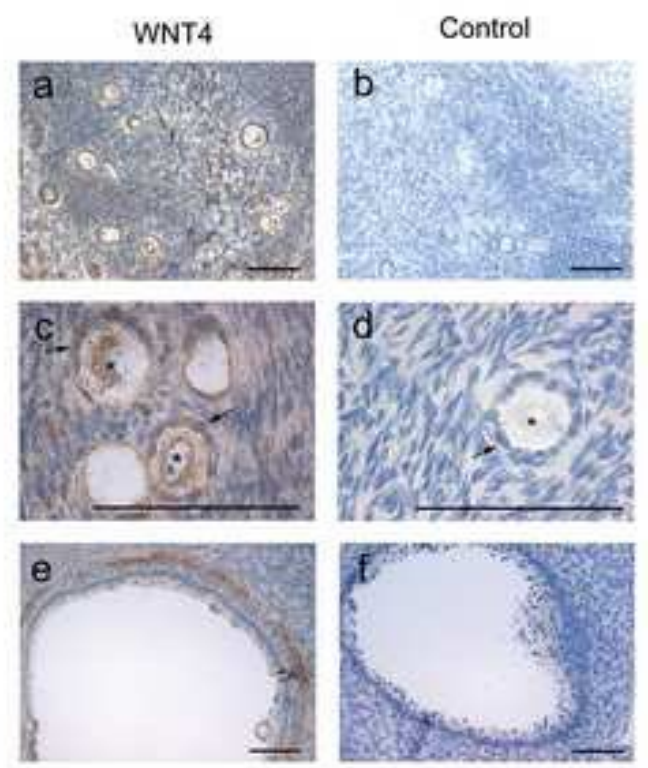

Adrenal gland
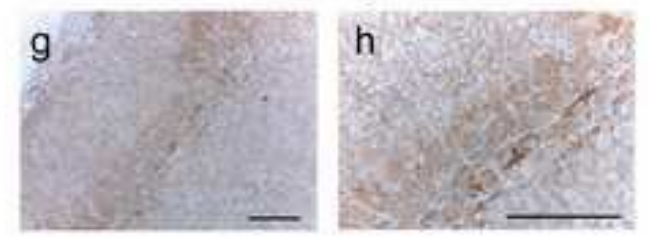

Testis
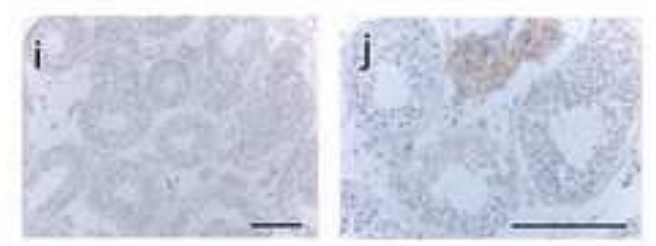

Figure 3. Apoptosis in Wnt4-deficient and wild-type mouse ovaries. Apoptotic cells were counted in sections of ovaries of different gestational ages: $12.5 \mathrm{dpc}(\mathrm{A}$ and B), $14.5 \mathrm{dpc}(\mathrm{C}$ and $\mathrm{D}), 16.5 \mathrm{dpc}(\mathrm{E}$ and F) and newborn ( $\mathrm{G}$ and $\mathrm{H})$, and the numbers of cells were adjusted according to the size of the section. The numbers of apoptotic cells were highest at $16.5 \mathrm{dpc}$ in both genotypes. However, a markedly enhanced rate of apoptosis was observed in Wnt4-deficient animals at gestational ages of $14.5 \mathrm{dpc}$ and 16.5 dpc. Scale bar $100 \mu \mathrm{m}$. 

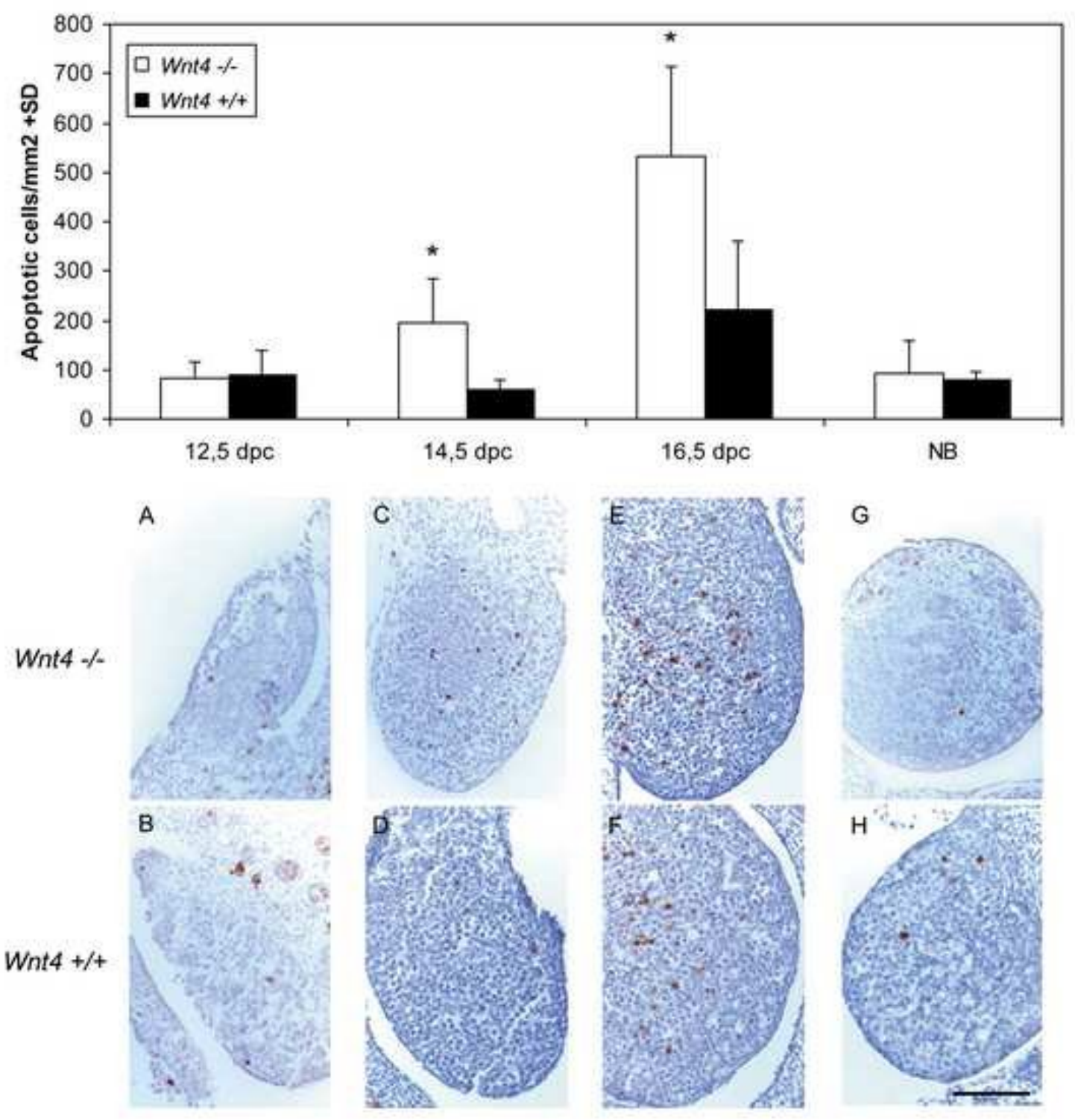

Figure 4. Immunohistochemical staining of Bcl- $\mathrm{X}_{\mathrm{L}}$, Bok, TRAIL, GATA-4, FOG-2 and aromatase in Wnt4- deficient and wild-type mouse ovaries. All the studied proteins were present in both the Wnt4 deficient and wildtype ovaries and no marked differences were detected between the two genotypes. 


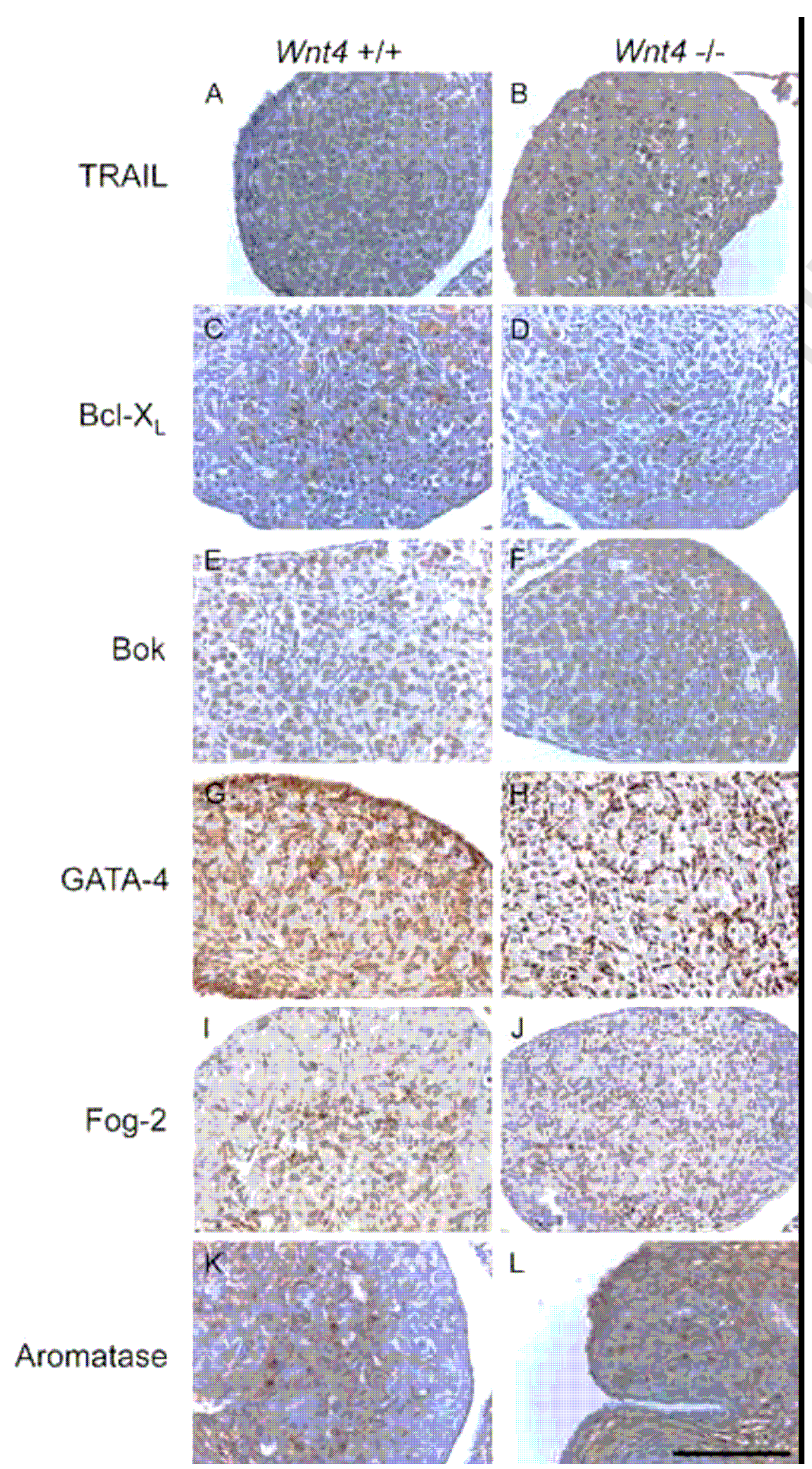


F

Page 17 of 17 